\title{
Performing "home" in the sharing economies of tourism: the Airbnb experience in Sofia, Bulgaria
}

\author{
MAARTJE ROELOFSEN
}

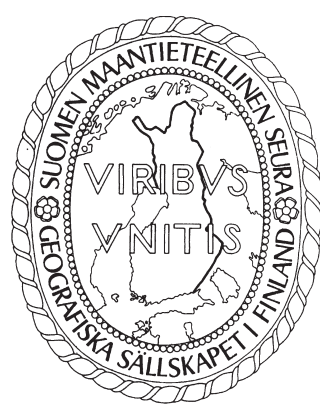

Roelofsen, M. (2018) Performing "home" in the sharing economies of tourism: the Airbnb experience in Sofia, Bulgaria. Fennia 196(1) 24-42. https://doi.org/10.11143/fennia.66259

$\boldsymbol{\nabla}$ This article explores how "home" is performed in the emerging sharing economies of tourism, drawing on the example of Airbnb in Sofia, Bulgaria. Based on an (auto)ethnographic approach, this article analyses the sometimes contested ways in which both hosts and guests engage in the everyday embodied practices of home-making. In doing so, it challenges Airbnb's essentialized idea of home as a site of belonging, "authenticity" or "localness". It also shows how the political and historical specificities, as well as the materialities of people's homes significantly shape the ways in which ordinary practices of homemaking play out and consequently affect feelings of (un)homeliness as part of the Airbnb experience. By using performance theory as an analytical framework, this article seeks to contribute to a critical understanding of the contemporary geographies of home in relation to the global sharing economies of tourism, one that is attuned to openness, interrelatedness, and a constant mode of becoming.

Keywords: home, commodification, performance, autoethnography, tourism

Maartje Roelofsen, Department of Geography and Regional Science, University of Graz, Heinrichstrasse 36, 8010, Graz, Austria \& Department of Geography and Planning, Macquarie University, Building W3A Room 433, Sydney, NSW 2109 Australia. E-mail: maartje.roelofsen@mq.edu.au

\section{Introduction}

In the past decade, tourism has witnessed the rise of a "sharing economy", a digitally based economy that putatively grants "consumers" temporary access to each other's "under-utilized" assets (Frenken \& Schor 2017). The platforms that act as intermediaries in this economy provide the online structures that enable a wide range of value-creating activities (for a recent critique of the "platform" metaphor, see Gillespie 2017). Perhaps one of the most cited and contested examples of tourism's sharing economy platforms is Airbnb, which facilitates the exchange of peer-to-peer accommodation and hospitality. The platform currently lists over 4 million homes worldwide and has assisted over 260 million guest arrivals since 2008 (Airbnb 2017). With the choreographing power of its networking technologies, contact is established between hosts and guests around the globe. Airbnb enables hosts to monetize their personal space (bedrooms or entire homes) and their labour of care in a bid for (supplementary) income. Conversely, Airbnb guests may book and pay through the platform for staying and being hosted in these spaces for a particular period of time. The Airbnb platform claims that travellers can supposedly experience what it means to "live a local life" by staying in people's homes, and - in so doing - "belong" to distant places (Chesky 2014). This suggests that the platform is

(c) 2018 by the author. This open access article is licensed under a Creative Commons Attribution 4.0 International License. 
both enabled by and productive of certain imaginaries and spatialities of home, rooted in an idea of collective global belonging. By tapping into everyday lives at the level of the household, travellers may supposedly experience "authentic" local cultures away from the "beaten track", signifying a "reflexive and daring traveller identity in opposition to that of the mass tourist" (Gyimóthy 2017, 66). As "locals" become the intermediaries who interpret the places they live in for tourists, such tourism experiences ostensibly center on the relationships between hosts and guests in place (Richards 2017).

Accommodation exchange platforms like Airbnb have contributed to a profound social transformation of many places around the world (Russo \& Richards 2016; Dredge \& Gyimóthy 2017). In recent years, civil society and grassroots movements and housing advocates have raised serious concerns over Airbnb's role in accelerating gentrification and the disruption of housing markets. In line with these developments, scholars have started to take stock of the "Airbnb effect" in/on cities (Arias Sans \& Quaglieri Domínguez 2016; Cocola-Gant 2016; Cocola-Gant \& Pardo 2017; Wachsmuth et al. 2018) while other studies aim at informing future urban policy and planning in response of these recent trends (Lee 2016; Gurran \& Phibbs 2017). These interventions have provided important evidence of the growing impact of the platform on a local, national and global scale. However, the fundamental site that is essentially commodified in this economy - the home is of lesser concern in the body of literature that examines Airbnb's socio-spatial impacts. Little consideration has been given to, for example, the everyday practices, social relations and emotions that intersect in these places, and simultaneously contribute to constituting homes as public as well as political worlds (Blunt \& Dowling 2006, 26; but also, Marston 2000 on the inter-relation between the household and other scales).

Another contentious and relatively unchallenged aspect is that platforms like Airbnb promote home as a site of belonging, "authenticity" or "localness" in an increasingly globalizing and alienating world. Such accounts emphasize the normative association of home with positive values. So far, little attention has been paid to how the processes of commodification of everyday lives may be disruptive and contribute to the emergence of entirely new ways of being at home. Taking into account that people's sense of self and "feeling at home" rely on the social and emotional relationships in these spaces (Blunt \& Dowling 2006), one may question how home is made and unmade when relative "strangers" move in and out of home with each new transaction.

The main objective of this paper is to examine how home is performed through everyday homemaking and hosting practices of both hosts and guests in the Airbnb economy. It intends to capture the ways in which "co-performing home" morphs along with subjective understandings of home. It also takes into consideration the materialities of people's homes and how they shape the ordinary practices of homemaking. In doing so, I have relied on a combination of ethnographic and autoethnographic research, which took place in Sofia, Bulgaria over a period of three months in 2015.

In the following section, I start by questioning how home has been conceptualized from a variety of theoretical perspectives, and consequently, what role home has played in the (re-)production of capitalist and late-capitalist values. After presenting my methodology, I provide an empirical account of how home is enacted through "home-making" practices in the Airbnb economy in Sofia, Bulgaria. Through the perspectives of my hosts and myself, I illustrate the diverse and sometimes contested meaning of home and how myriad performances bring home into being.

\section{Shifting meanings of home}

In the disciplines of sociology, geography, and anthropology, as well as housing, migration, and cultural studies, scholars have been committed to a critical study of home for several decades now (e.g. hooks 1991; Massey 1992; Ahmed 1999; Blunt 2005; Blunt \& Dowling 2006; Duyvendak 2011; Brickell 2012; Lloyd \& Vasta 2017). In these debates, home has been re-conceptualised as a political space where identities are produced and sustained through power relations, reinforcing structures of inclusion and exclusion. In the paragraphs that follow, I first selectively engage with a literature that discusses the changing role of home in (re-)production of capitalism and late-capitalism. After briefly discussing the meaning of home in the sharing economy and tourism, I then expand on the idea of home as being practised and "performed". 


\section{Home and capitalism}

In Marxist accounts home has been conceptualized as a site for the reproduction of the social relations that maintain capitalism and of the material bases upon which social life rests (Gregson \& Lowe 1995; Blunt \& Dowling 2006). Home, here, is described as a site where workers recover in order to continue their work; a place that serves to maintain individual productivity under capitalism. In these accounts, the caring and affective labour taking place at home is generally not considered to produce "value" and is therefore accordingly not considered as (waged) work. At the same time, "home" ownership is seen as instrumental to the success of capitalism and to forward an ideological agenda aimed at economic efficiency and growth (Mallett 2004, 66). In many Western countries, home-ownership is supported by governments through state policies, and heavily promoted by the real estate industry (Knox \& Pinch 2014). It supposedly stimulates workers to remain committed to their jobs in order to pay off their mortgages, and signals identification with and the incorporation of capitalist values (Harvey 2008). In the last two decades, the global struggles over housing and associated practices of displacement and dispossession are also testimonies of the un-making of home spaces (Brickell et al. 2017). On-going external pressures such as the affordability of housing, housing instability, and lack of autonomy may also affect whether or not one feels at home (Bate 2017; Lloyd \& Vasta 2017). For example, under the pressure of tourist investors, long-term tenants in Barcelona have dealt with expulsions, harassment, rent increase, and affordability problems (CocolaGant 2016).

Feminist scholars have problematized and challenged the earlier conceptual separation of the production and reproduction spheres. The manifold everyday practices people engage in complicate and pervade the supposed borders between "work" and "nonwork" (Mitchell et al. 2004). Moreover, feminist scholars have highlighted the gendered nature of the separation between "work" and "nonwork". Historically, cultures have equated women with home where they serve, maintain and nurture men and children (Young 1997, 134). Women remain, until today, the primary "homemakers" around the globe (Bowlby et al. 1997; Duyvendak 2011). The unwaged caring and affective labour that takes place outside the factory walls and offices is in fact value-(re)producing and should be understood as work (McDowell 2004; Mitchell et al. 2004). The household as the primary site where labour power is regenerated is thus "as inextricably bound up with the operations of capitalism as are capital and the state" (Marston 2004, 176).

\section{Home in late capitalist economies}

Under the impact of globalization and related information and communication technologies, a profound qualitative transformation in the nature, form and organisation of labour has taken place (Gill \& Pratt 2008). In late capitalist economies, workers are often expected to be temporally flexible and spatially boundless. By ways of encouraging this work ethos, the spheres of work and home are progressively and oftentimes deliberately defused (see Hochschild 1997 on the decline of "home-athome"). With the "extensification of work", or, the exporting of work across different spaces and time, people increasingly work from home leading to an "overflow of work into wider social life" (Jarvis \& Pratt 2006, 338).

Yet another trait of this transformation is the working spaces that purposely resemble home and/ or should make workers "feel at home". Googleplex (Google's headquarter) for example, incorporates an array of facilities, services and activities previously associated with the private sphere. Here, workers are incentivised to bring their children and pets along to work, get in-office haircuts and massages, use on-site sports facilities, play games, get their clothes dry cleaned and take up classes in personal and spiritual development. While such "home-like" work environments may provide workers the comfort and ease of having certain necessities available within arms-length, another objective of these defused spatialities is to incentivise, control and enhance the productivity of the employees. They engender what Mitchell, Marston and Katz (2004, 3, italics in the original) define as "the interpellation of subjects as life workers - the rendering of permanently mobilized bodies in new kinds of technologies of power". 
The labour performed in late capitalism also increasingly resembles the labour previously associated with the affective and caring spheres of home. The production and delivery of services, information and experiences, through activities such as entertainment, advertising, health care and finance, are realized through labour that produces immaterial products, knowledge, information, ideas, images and affect (Hardt 1999; Hardt \& Negri 2000). This form of labour, again, continues to blur distinctions between what is work and what is not, when one works and when not, and where one works and where not, allowing for an identification of both the work sphere and home with economic activities, whether these activities are waged or not. The blurring of these distinctions is further encouraged by current neoliberal agendas in order to produce insecurity in the absence of fixed contracts and the proliferation of cheap unprotected labour. This echoes a "feminization of work" by which workers, male or female, are increasingly precarious and in a constant state of insecurity, and therefore easily subject to exploitation (see e.g. Adkins \& Jokinen 2008).

\section{Home in the sharing economy and tourism}

The labour that is enabled through peer-to-peer accommodation platforms like Airbnb, appears not much different from, if not an exacerbated form of, the aforementioned precarious labour under late capitalism. What is crucially different, however, is that these platforms explicitly mark out people's private spaces - homes - as sites for and of production and consumption; a potential incomegenerating sphere. Botsman and Rogers (2010) in their conceptualization of the sharing economy, optimistically conceive of the home as an "underused good", or, an asset that sits "idle" that could be made available to others who want to use it on a temporary basis. In the "sharing" economies of tourism, home is not merely the site where (household) labour is carried out, but in its entire materiality and imaginary is conceived of as a commodity - whether paid for or not. Unlike quasi-commercial and commercial home enterprises such as homestays, guesthouses and bed \& breakfasts, both hosts and guests are reviewed and rated for their performances in their respective roles. As such, responsibilities for and expectations of "homely" experiences rest on the shoulders of both "consumer" and "producer" in this sharing economy.

Whereas peer-to-peer accommodation platforms may be a relatively new phenomenon, quasicommercial and commercial home enterprises such as homestays, guesthouses and bed \& breakfasts have long been contentious sites of study (Lynch et al. 2009). In such forms of tourism accommodation, intimacy may also have commercial value. Depending on the demands and behaviour of guests, the hosts constantly (re)draw the lines between the public and private spheres in those sites (Andersson Cederholm \& Hultman 2010) whilst employing different strategies for making guests "feel at home" (Sweeney \& Lynch 2007). This work challenges the previous notions of home, in particular those commonly proposed in the tourism literature. In tourism studies, home and tourism have been for long theorized as opposite ontological worlds (Larsen 2008). It is the ordinary and mundane home one escapes from or returns to after having fulfilled one's desires in places elsewhere in the world, through travel. As such, home is treated as a separate sphere, a point of the departure or return, or is explicitly left out in the conceptualization of social life (ibid.).

In an age of high mobility and changing local contexts, the realities and practices that constitute home in the $21^{\text {st }}$ century have ostensibly changed. They have arguably spurred an increased sense of translocal- or transnational belonging (Lloyd \& Vasta 2017). Tourism enables "different modes of attachment to and detachment from places, cultures and people; different modes of belonging in the world; hence we may conceive of tourism as a way of positioning oneself in the world" (Haldrup 2009 , 54). Tourist performances and experiences, Haldrup (ibid.) argues, are also an important vehicle for the emergence of cosmopolitan orientations in everyday life.

In the past decade, platforms like Airbnb and Couchsurfing, have (quite successfully) tapped into a cosmopolitan fantasy of "being at home in the world" (see Germann Molz 2007). Through social networking technologies, such platforms have connected millions of strangers all over the globe in their desires for more individuated encounters. By enabling peer-produced-hospitality in everyday and homely environments, these platforms ostensibly centre on experiences in rather than of place (Russo \& Richards 2016). As such, they have also inspired new forms of sociality (e.g., Germann Molz 
2012, 2014) and have refuelled debates on cosmopolitanism (Picard \& Buchberger 2013; Zuev 2013). These accounts also suggest that travel may open up new territories where people feel at home. In an analysis of accounts of round-the-world travelers, Germann Molz (2008) contends that - in their privileged positions - travelers may also feel at home in mobility (also Ellingsen \& Hidle 2013). By engaging in "small acts, embodied practices, and familiar routines" travellers make themselves at home "online, on the road, and in the world as a whole" (Germann Molz 2008, 337). The sense of "being at home", Accarigi $(2017,192)$ argues, can be disassociated from a geographical location and "replaced by belonging through specific everyday practices".

To take on a perspective of home as "practiced" or "made" rather than to "be at home", Lloyd and Vasta $(2017,4)$ argue, offers "a new set of possibilities to make ourselves at home in relation to others". However, home is not merely "made" through the interrelation of social relationships, spaces, and materialities. Home may also be understood through "unmaking", a "precarious process by which material and/or imaginary components of home are unintentionally or deliberately, temporarily or permanently, divested, damaged or even destroyed" (Baxter \& Brickell 2014, 134; but also, Brickell 2014). What is said, done and "acted-out" - our performances - transform spaces and places into what they come to be or what we want them to become (Gregson \& Rose 2000). These performances are embodied and give way to a corporeal approach to an understanding of home in tourism's sharing economy. In the following paragraph, I briefly expand on the performative approach that I have taken in this research, and how consequently this approach has influenced my choice to employ a set of qualitative methods.

\section{Approaching the home through performance}

The arguments presented in this paper are informed by the theories of performance and the role of performance in bringing social life into being. Here, I rely predominantly on the work of Erving Goffman and Judith Butler, recognized as two of the most influential "performance" theorists in the geographical literature (Gregson \& Rose 2000). While their conceptualizations of performance differ, the aspects of both conceptualizations have been key in the interpretation of home in this paper. Firstly, I rely on Goffman's (1956) dramaturgical approach, which argues that social life may be thought of as "staged" by conscious actors who perform for an audience according to the scripts and codes of conduct. By distinguishing between a front- and backstage, Goffman suggests that the self performs various roles according to the different stages one finds oneself on. The "frontstage" signifying those spaces (un) intentionally employed for (routine) performances that require a certain setting, décor, and/or appearance. The "backstage", on the other hand, signifying those spaces that are relative to the given performance; reserved for preparation, practice, recovery and retreat. I employ Goffman's notion of performance in this paper to analyse the possible structural divisions of social establishments within the context of the Airbnb "home". In particular, I examine how home (both materially and symbolically) is produced, maintained and regulated as a "tourist stage" (MacCannell 2013).

Secondly, I employ Butler's (1986, 1988, 1990, 2004) conceptualization of performance. In Butler's theory of performance, which refers predominantly to the questions of sexuality and gender, identity is not so much a construct; rather, it relates to what we do or what we "perform" (Butler 2004). As such, performance is imbued with an ability to destabilize and transform social identities that are all too often considered stable. Like Gofmann's "codes of conduct", Butler argues that norms serve as guidelines in social intercourse throughout life, consequently guiding one's performances. For norms to come into effect, embodied practices need to be repeated. However, the repetitions of embodied practices are never entirely the same; "bodies never quite comply with the norms by which their materialization is impelled" (ibid., xii). In fact, they are reinterpretations of what is assumed must be performed, calling the absolute force of the norm into question. Moreover, performances, can also offer "an opportunity to mark subjectivity" by rebelling against the codes of conducts, scripts and norms (Edensor 2001, 75). In the work of Butler, the notion of performance thus allows thinking beyond what one is, and focuses instead on what one becomes. Employing Butler's notion of performance in this paper allows considering those performances that deviate from a template of home. 


\section{An (auto)ethnography of home}

The present study relies (in part) on autoethnography. In performing autoethnography, the living and embodied subjective self of the researcher is considered an active agent and a constitutive part of the research process; the researcher is the "epistemological and ontological nexus upon which the research process turns" (Spry 2001, 711). In my capacity as a guest, I thus considered myself an active agent in making-home rather than a passive observer who sits on the receiving end of the Airbnb experience. An autoethnographic approach allowed me to focus on my embodied and affectual encounters in place. As a researcher-guest, I self-witnessed and committed my body to the intimacies of experiential encounters. In doing so, Caroline Scarles argues, we become witness to a place for ourselves $(2010,911)$. As a relational approach, autoethnography enables a variety of ways to engage with the self in relation to others, to culture, to politics, and other aspects (Allen-Collinsion 2013).

My autoethnographic accounts of the day were either recorded in writing (in a diary) or on video (via my smart phone). These accounts reflected the practices and interactions that made an impression on me during my stay. At the same time, I took note of the materiality and sensory richness of the home as these played a crucial role in enacting interactions (Haldrup \& Larsen 2006; Haldrup 2017). I took care to observe how things relate and through what practices, rather than what they essentially are, in a static form. Adopting an autoethnographic approach allowed me to directly explore how our "homely" performances, like touristic performances, "involve, and are made possible and pleasurable by, objects, machines and technologies" (Haldrup \& Larsen 2006, 276, but also Accarigi 2017). Analysing my diary entries and videos eventually allowed me to trace how "feeling at home" shifted according to an amalgam of materialities, experiences and embodied practices as well as the changing relationship to my hosts over time.

To study how home was (un)made through the performances of both the host and guest, I stayed in 11 different Airbnb homes in Sofia, Bulgaria for respectively two to five nights each. During these stays, I was hosted by Anne, Nico, Eva, Lisa, Pia, Jeny, Maria, Tina, Adrian, Ria, Iordan, and Vera. Indepth interviews were held with each of these hosts and I refer to these interviews directly and indirectly in this paper. The interviews took place according to the hosts' preferences. On most occasions this meant at home, several other interviews were conducted in bars and restaurants in Sofia. The interviews were taken individually and lasted between 15 minutes to approximately 2.5 hours; however, casual conversations that also informed my research took place throughout my stay and were taken note of in a notebook. All interviews were taped with the hosts' consent with the exception of Ria's interview. Prior to this interview Ria expressed her worries for possibly being exposed and sanctioned by the authorities and hotel industry for using the Airbnb platform. Ria asked me to take notes during the interview instead. The interviews were transcribed verbatim and, together with other data, were analysed through qualitative data analysis software MAXQDA. The textual accounts of the interviews were searched for common themes related to the research objective. In this study, I have used pseudonyms to guarantee my hosts' anonymity.

\section{Selecting Airbnb homes in Sofia, Bulgaria}

The hosts and their homes were first and foremost selected based on their set overnight rates (between $€ 10$ and $€ 20$ ) as I relied on a limited budget. Secondly, hosts who received ratings and reviews indicating recurring unacceptable behaviour or homes that were considered unfit by previous guests were not taken into consideration for safety reasons. An additional condition in the selection process was that the homes had to be available for the requested days during the months in which the "fieldwork" took place.

As I took on an active participant role, my hosts were provided with a full explanation of my position as a researcher and what my research was about. When making booking inquiries, I informed the hosts that my stay in Sofia was tied up to my research and asked if they were interested in sharing their experiences with me. The large majority replied positively to my inquiries whether or not they were able to host me. When I stayed in Sofia, I had already been using Airbnb for personal travel for over a year. In consolidating my booking requests in Sofia I was thus able to rely on 
numerous positive reviews and ratings that I received from my previous Airbnb hosts. This form of "digital social capital" has arguably aided me in getting access to the "field"; moreover, the positive reviews that I received after each new stay in Sofia arguably aided my access to other Airbnb homes.

During these 11 stays, nine out of 12 self-identified "hosts" were present on the premises most of the time throughout my stay. During the other stays my hosts sometimes spent time with me during the day or evening, but slept elsewhere (referred to as Pia, Maria and Ria in the findings). During five of my stays, other people (tenants, family members, partners and friends) were sleeping on the premises too but rarely engaged with me throughout my stay. Some introduced themselves to me but took little or no responsibility in the hosting activities. With few exceptions, my hosts were white, middle-class highly educated Bulgarians who resided in Sofia and used the platform for their own travel endeavours. Except for Anne, all of my hosts spoke English, were (highly) mobile and to (some degree) open to cultural difference. They also used the platform to increase their earnings rather than relying on Airbnb for a sole income. This attests to other studies on the sharing economies of tourism as exclusive marketplaces for cosmopolitan citizens; a community marked by privileges such as the political right to mobility and the means to travel as a requirement to "be at home in the world" (see Germann Molz 2007, 2008; Picard \& Buchberger 2013; Zuev 2013; Schor 2017).

Unlike other cities in Europe, the municipality of Sofia has not yet imposed specific rules and regulations on the Airbnb platform and it users. At present, short-term rental platforms are not treated any differently from other commercial short-term rental agencies. However, under the Bulgaria Tourism Law, homeowners are officially obliged to register their apartments with the municipality in order to obtain a license to rent them out to tourists (Ministry of Tourism Bulgaria 2018). Although no official numbers exist, it has been speculated that a large majority of the hosts on the platform currently do not possess such a license (Kapital 2017).

\section{Researching the Airbnb home}

While this study is situated in academic literature focussed on the global political economy of Airbnb, the aim of this (auto)ethnography is not to generalize or to explain the experiences of a wider universe of Airbnb hosts. Rather, it depicts a series of the case studies of homes and encounters between myself and the hosts, each detailing the specific culture and micropolitics of the related context (see Mohanty 2003).

It is important to state that being a white, able-bodied, middle-class woman with a privileged Northern European upbringing makes my knowledge necessarily partial, contingent, and situated (Haraway 1991). On many occasions I found myself wondering what gave me the right to write about the lives and homes of Eastern European "others"? There is of course no straight-forward or easy answer to this question. I have, however, attempted to closely listen to my participants and tried to detail their stories, worldviews and social realities in a way that hopefully shows their inherent multiplicity and plurality.

My positionality has indeed also affected my access to the field. Some of my hosts expressed that they were positively inclined to accept my booking request based on their judgement about my online Airbnb profile. This profile included a picture and details on my profession, education and other biographic details. Several hosts explicitly mentioned that they only accepted booking requests from people who reflected their preferences in terms of gender, class, age, sexuality, religion and 'race' (see also Karlsson et al. 2017). Ria, for example, declared that she would not accept bookings from non-white and/or Muslim guests. Various cases in my research confirmed the explicit and implicit practices of discrimination that occur on the platform (as shown in Edelman et al. 2017). In other words, the processes of inclusions and exclusions shape Airbnb homes - like they do other non-commoditised homes (see also Blunt \& Varley 2004).

\section{Setting the "stage". Material accounts of (post-) socialist homes}

With some exceptions, most of my hosts live in a one-family (high-rise) apartment, which were built between the 1960s and 1980s. Bearing concrete constructions, these apartments were marked by a 
single coherent architectural style, a result of the socialist regime's embrace of a specific strand of modernist architecture in a context based on anti-capitalist and anti-bourgeoisie ideologies and driven by the political objective to provide everyone with a home (Hirt 2006). The materialities of these homes carry with them significant historical and political meaning. At the same time, and to speak with Haldrup and Larsen (2006), such materialities crucially condition the practices of home-making and the feelings of homeliness in several ways even today. By fleshing out some of these "inherited" socialist materialities I firstly show how specific objects and home spatialities both enable, constrain and guide performances of Airbnb homes in Sofia. Secondly, I reflect on how some of these socialist material legacies have become part of new touristic values and are purposely marketed as such.

\section{Energy monopolies and the visceral home}

Most of the apartments I stayed in are still powered by centralized heating and power systems that were initially installed and operated under the socialist regime. Since Bulgaria's transition to a socalled "free market regime" and to liberal democracy, these systems have been predominantly operated and owned by private (foreign) companies after the state sold off its majority stake, creating true energy monopolies in this way (Minchev 2013). These companies are occasionally termed "the mafia" in the accounts of my hosts; a name arguably earned for their practice of charging Sofia's residents constantly fluctuating and highly inflated fees while providing unreliable services. High electricity bills, together with low wages and pervasive employment insecurity, have been at the root of the nationwide anti-government protests in 2013 (Tsvetelia 2013; Koycheva 2016); protests that several of my hosts have actively participated in (and mentioned in the interviews). Two years after the revolt in 2013, the owners of these centrally operated heating systems still shape how homes are felt, lived and experienced in Sofia. On numerous occasions, and for extensive periods of time, there was no central heating flowing into the homes where I was staying, bringing indoor temperatures closer to outdoor temperatures, which averaged between 0 and +15 degrees Celsius at that time of year. The enduring cold that I experienced in some of these homes came with a constant sense of unease and eventually brought about illness on my part.

Home, throughout my Airbnb experience in Sofia, inadvertently became a profound affective, sensuous and visceral experience; an experience that made me long to be "elsewhere" on many occasions. It led to the enduring feelings of non-belonging, paradoxically running contrary to what the Airbnb commercials would like guests to believe. As the cold conditioned and significantly restricted my embodied practices, I found myself leaving the apartments in search for better-heated public spaces during the day. Consequently, the time to form (potentially) affective relations of belonging with my hosts became limited as I stayed away from their homes until the late evenings. Once back, I would promptly retreat to the solitude of the bedroom where I could stay under the covers fully dressed. This echoes Haldrup's $(2017,53)$ account of the important role materialities play in enacting relationships between people, as well as "reinforcing bonds as well as boundaries between the home and the world outside". Although I tried to make up for my absence by inviting my hosts along for walks and meals outside, my alienating habits eventually left me feeling inadequate as a guest. A guest who - in the political economy of Airbnb - also gets rewarded (or disciplined) for their (un)homely performances through review and rating systems, and the algorithms that the platform operates to ensure "quality control" (see Roelofsen \& Minca 2018, for a critical discussion of these systems of measurement).

The constant cold due to the lack of adequate heating systems thus became a mere obstacle to me feeling at home. It also showed that the materiality of the intimate and personal spaces of home in Sofia is deeply interwoven with wider national politics and power relations. Home, indeed, was not "a secluded 'private' space but a space in which outside forces make their entry" (Haldrup 2017, 53). The materialities that underlie post-socialist housing in Sofia came to determine the conditions by which bodies are both enabled and restricted to engage in the ordinary practices of homemaking, particularly during the colder months of the year. Several hosts shared with me during their stay how they dealt with the insecurity of not being able to pay their energy bills and consequently being unsure if they could provide their guests with the warm and "homely" environment they might be 
used to in their own homes. However, at the same time, an additional Airbnb income enabled them to continue paying some of their household bills, thus appropriating the platform to fulfil their own homely needs. Although this allusive interdependence on the platform was never easy, it also opened up a space for alternatives.

\section{Home heritage}

Home and place identities come about through the creative expressions of hosts and their display of symbols and artefacts in hospitality practices (see also di Domenico \& Lynch 2007). Pia, one of my hosts, shared with me how she created value out of the historicity and materialities that are so specific to the multiple homes she puts on display through Airbnb platform. As an intermediary, Pia takes on the work of representing several Airbnb home-owners in Sofia, receiving a small commission for welcoming guests and being available to assist them throughout their stay. The home-owners she represents either only speak Bulgarian or do not have the time nor interest to engage in the hosting labour but are interested in earning the related income. These particular homeowners do not live in their homes permanently when guests are present. They often outsource the labour of cleaning their homes to others, making their presence around the home limited or non-existent.

Although Pia does not spend a lot of time with guests at these homes during their stay, she takes on an important role in framing and (re-)distributing socialist values through the homes under her umbrella on the Airbnb platform. Pia argued that she has perceived among Airbnb guests a certain interest for everyday life under socialism, a desire for the supposed "authentic" socialist Other and their spaces. Pia's observation mirrors MacCannell's (2013) critical account of tourism, according to which the tourist alienation of their own life has led them to search for "reality" and "authenticity" in the purer lifestyles of other cultures.

The tourist, here, can be conceived as an emblematic modern subject that seeks to escape the humdrum of ordinary life and attempts to find "an outlet for existential anxiety over the precariousness of the modern condition" in tourism (Minca \& Oakes 2011, 6). However, such desires are often not well understood by Pia's clients who actually used to live such lives under socialism in the homes they now rent out. They find it hard to think of marketing an essentialized socialist identity and culture through their homes on the platform. The materiality of home evoked involuntary memories of otherness (Morgan \& Pritchard 2005, 42); a socialist past they no longer identified with and tried to dissociate from (see also Kaneva \& Popescu 2011). Notwithstanding, Pia shared with me that she continues to recommend her "clients" to conserve their homes in "original" and uniform socialist character and refrain from polishing the interiors into a "uniform" globalized and capitalist "IKEA jacket". Pia suggests to the homeowners not to replace their domestic material objects acquired under socialism with "modern" ones, as socialist life and decor has recovered its value under tourism. They had the potential to authenticate the guest's experience. What her clients consider "bad taste" or backward - furniture, household equipment and technologies, and decorative items from the socialist era - was picked up by Pia as potentially value-generating. In their absence at home, such items referred to the life histories of their owners, and, like souvenirs, had "the effect of bringing the past into the present and making past experience live" (Morgan \& Pritchard 2005, 41). Such artefacts had the potential to contribute to a lived experience of socialism, a multi-sensory experience by which home could be seen, felt, heard, and smelled.

This gives way to thinking of the Airbnb home as an "exhibit of itself". A home as "heritage" by which some hosts or host-representatives like Pia give their "ways of life" and homes a second life (Kirshenblatt-Gimblett 1998, 150). As certain materialities and historicities have different meaning and significance under tourist consumption, it goes to show that they can also give renewed purpose to homes that were once conceived as less valuable and in need of improvement. Being perceived as "exotic", everyday objects connected the contexts of "home" and "away" into a setting for the tourist performances (Haldrup 2009, 55).

Pia and the other homeowners feel they exert a certain level of control over the ways in which their homes get commodified through Airbnb - together they determine themselves the extent and ways in which their homes get absorbed in the platform economy and for what they put it to use. 
This echoes Mary Louise Pratt's (2008) concept of the contact zone, meaning the spaces where cultures intersect and grapple with each other. Emerging from this zone is the phenomenon of "transculturation", which challenges viewing encounters from one cultural perspective or from opposition (ibid.). Rather than assuming it is the Airbnb guests who "consume" the culture and homes of their hosts during her visit, some hosts purposively select those materials and practices that are deemed valuable by their visitors. Employing the contact zone as a tool then becomes a more affirmative way of describing the complex transformation of Airbnb homes.

\section{Sharing home with strangers}

In the Airbnb experience, everyday practices that are usually done alone or between people in an intimate relationship are given value by practicing them with strangers "in the home." They include socializing and eating together, commuting, taking a shower, walking around in pyjamas, relaxing on the couch, and sleeping, amongst others. This suggests that contemporary tourism (and society more broadly) increasingly relies on affective capacities and practices marking out people's private spheres (Veijola et al. 2014). Having strangers under the same roof also gave my hosts a different lived experience of home, which positioned them differently in relation to their home. Eva shares:

"In a way, [Airbnb] is always a dangerous thing. That you go to someone's house and you live there, you sleep there. At the same time, I am hosting somebody I do not know. You will use my apartment, my flat, my toilet, my everything. I am leaving all my stuff there, my expensive belongings. There is always this dangerous part in the whole experience. [And] many times the guest is too cold [referring to their ways of interacting]. You will be like: 'This is your key, if you need something this is the map, this is where I have my coffee, this is a good restaurant. Thank you. This is it.' And sometimes it is totally the opposite: 'Come have breakfast with me, tell me something, walk with me while I go to work.' And the experience is totally different because [that person] changes your entire experience."

Sharing home with strangers, as Eva's account suggests, is a symbiotic process of unmaking and remaking home (Baxter \& Brickell 2014, 135). It changes along with the different social and emotional relationships that are formed between hosts and guests. What Eva's account also points out, is that sharing home may challenge home as a source of "ontological security" (Dupuis \& Thorns 1998) and feeling ontologically safe. In the Airbnb experience, where lockable bedroom doors often lack, sleeping is drawn into a sticky negotiation with every new stay. Veijola and Valtonen $(2007,23-24)$ in their analysis of sleep in tourism, contend that sleeping, today, is one of the most private and intimate acts: "you either sleep alone or with someone you know well, [the] dormant body is not visible to strangers".

My sense of home and ontological safety was severely disrupted when I rented Maria's entire home. I had rented it in its entirety precisely to get a break from sleeping in the presence of strangers. Hours after having checked into Maria's apartment somebody repeatedly and forcefully knocked on the front door. After a minute of being startled and not knowing what to do, I finally opened the door. An intoxicated man introduced himself as Maria's husband. He was the owner of the apartment and demonstrated a set of keys in his hands. Without asking permission to come in, Maria's husband passed me in the hallway, and made himself comfortable at the kitchen table. In the minutes that followed he subjected me to an interview about my stay whilst giving me a slurred speech about the state of tourism in Bulgaria. He had been informed about my position as a tourism researcher by Maria, which I had also detailed in my profile. After half an hour he left, and I realized he had trespassed what was at least temporarily "my" home. I was left in a considerable state of uncertainty as his set of keys allowed him or anybody else to enter the apartment at any given time. My imagined sense of privacy and safety in that space had been wiped out in an instance. As my corporeal vulnerability was brought to "the forefront of my consciousness" along came several embodied consequences (Allen-Collinson 2013, 295). In the days to follow, I had my ears on full alert to listen if anybody was wandering around the front door. At night I left the lights on so I could see better if anybody came in. After two consecutive sleepless nights I decided it was time to move out - this home had been forcefully unmade. 
Airbnb homes in both my own experience as well as my hosts' experience thus became ambiguous sites of, at the same time, belonging and non-belonging. Places where various practices of trustmaking were by default part of the "homely" experience and the mutual endeavour of "makinghome". During my Airbnb stays with hosts present, such trust consolidated around an understanding and respecting of each other's emotional and bodily needs. In doing so, I continuously tuned into my hosts' daily intimate routines and to what I perceived as their "hygienic standards". I would make sure not to come home after $11 \mathrm{pm}$; not to use the shower in the morning before they did; or, waking up and moving around the living room and kitchen not too early but also not too late. Along with becoming overly concerned with keeping my bedroom in order (by making my bed every day and keeping my clothes and personal belongings stowed away), I disciplined and controlled my body in order to meet, what I thought, were socially accepted standards of being a "clean guest". I was careful not to make any loud or awkward sounds in any spaces of the home. Each time I visited the bathroom, I double-checked if I did not leave any bodily products behind that might socially or culturally be deemed as "dirt" or "waste" (Isaksen 2002). Through these embodied practices, I aimed to avoid provoking disgust in my hosts. Such practices ostensibly subscribed to my own ideas of "appropriateness", and to "culturally-validated values of 'proper' bodies and 'proper' femininity" (Fahs 2017, 192).

Besides relying on my social skills in bonding with my hosts, I thus engaged in various forms of affective and embodied labour in a greater endeavour of making each other "feel at home" throughout our stay. During everyday encounters with my hosts, I continuously smiled - an "embodied display and an act of amiable hospitality" (Veijola \& Valtonen 2007, 20-21). And in being overtly but not insincerely appreciative for things like a clean towel and a spontaneously offered cup of tea, I attempted to operate on my hosts' bodies as to "provoke a state beyond what can be cognitively communicated" (Dowling 2012, 5). Paradoxically, such practices ran counter to what I associated with being at home-at-home; a place where I could be emotionally unrestrained and enjoyed a (literally) embodied freedom. A place where I could be grumpy, loud, late, early, messy and above all dirty (Veijola et al. 2014, 1). Instead, I fully engaged in co-providing my hosts with a clean home as a mutual act of hospitality and a way to slowly rid my "strangeness" from their own home.

In a home that was not even mine, I "stage-managed", ordered, and disciplined myself, intuitively tuning in to the rhythm of my hosts' day. A tiring process that, in producing fatigue, drew me even further away from "home" but at the same time felt like a more ethical way to relate to these unknown others. Contrary to what Veijola and colleagues $(2014,3)$ suggest, stranger/guests may no longer be as messy as they have been theorized, especially in a reputation economy like Airbnb where hosting and guesting bodies are monitored, controlled and disciplined through its ranking modalities (Roelofsen \& Minca 2018). Instead, they may have become increasingly complicit in reproducing that same old "tidiness" paradigm that tourism theorists, planners, activists and tourists have become so fixated on.

\section{Bordering the private and intimate spatialities of home}

After our brief introduction, Anne instantly leads the tour of the two-bedroom apartment as part of her performance as host. The tour proceeds in moderate silence, as we both seem uneasy to express ourselves in a language we do not control very well. Anne leads, entering the different doors in the house. She first guides me to her son Nico's former bedroom, which is adjacent to her own bedroom and has access to a balcony facing the inner courtyard, which is now covered in snow. This is where I will sleep the next couple of nights. The 15-square meter room features a double bed, a desk, a chair and a couple of empty cupboards. Anne continues the tour through the kitchen and living room and shows me the workings of the toilet, which has some particularities to it. As she concludes the tour in the hallway, it becomes apparent that her bedroom is the only one that she will not show to me: the place where her body lays to rest will not be on display today.

In my Airbnb-stays, "home-tours" like Anne's were commonplace and served as an implicit bordering practice (see also Andersson Cederholm \& Hultman 2010) to negotiate the separation - or lack of separation - between shared private spatialities (e.g., the living room and kitchen) and the remaining 
intimate spatialities (e.g., the bedroom). In a similar vein, when Eva and Lisa toured me around their apartments, they made clear that I would be sleeping in their bedrooms while they would be sleeping on the sofa bed in the living room throughout my stay. In an interview Lisa recalls the importance of her bordering practice, "I try not to bother at all the people who stay with me. But I am always saying 'This is it - [pointing at the couch] - I will also stay here' so the guests have it in mind".

In this respect, Goffman's conceptualizations of the frontstage/backstage interplay in tourism seem to be implicitly operationalized in the first encounters with my hosts. However, while there seems to be a common understanding of "back-staging" - that is, defining spaces in the house where both my hosts and I would be able to retreat and rest - the act of deliberately delineating the "backstage" on part of the host implied that certain borders were already transgressed by the Airbnb guest's presence and/or needed to be respected by the guest's presence. What this shows, I would like to suggest, is that Goffman's sharp separation between front- and backstage in the framing of social relations is here put into question by the "literally" embodied negotiations between host and guest, and the related establishment of constantly blurred borderings in the home context.

The experiences I had during my fieldwork are perhaps more in line with a Butlerian understanding about the embodied performance of home. The presumed and/or aspired radical separation between front- and backstage was, on the one hand, endlessly challenged by the constant possibility of trespassing the related (in)visible borders making the "Airbnb-ed" spatialities of home. On the other hand, the hosts openly discussed the existence of a presumed backstage that the guest should not penetrate.

These very spatial practices reflect in many ways the fluidity of the literally embodied experience of hosts hosting in their own home. Such fluidity and complexities clearly emerged on multiple occasions and in multiple forms during my fieldwork. For example, host lordan set out to literally and figuratively "erase" himself/his body from his apartment by retreating to his own bedroom throughout most of his guests' stays. He would only make use of the newly constituted "common" spaces when he was sure the guests had left the apartment. Iordan explains he does so in order "to leave the most possible space to my guests", implying his own presence would stand in his guests' way of feeling at home. Iordan is not alone in performing such empty and silenced spatialities; when Airbnb guests stay over, Anne and Nico discipline themselves by "trying to be calmer", and try not to argue with each other in order "not to disturb guests". In a similar vein Jeny contends,

"[When hosting] I leave more time [in my daily routine] to interact with [guests] and not to somehow interrupt them when using the kitchen or the bathroom. I try to get into the rhythm of the guests somehow [...]. Also the whole family, like, we are coordinating our actions more, like, when everyone is going out and coming back. If the guests want something, this means somebody has to be [at home], always."

These practices give to think about the complexities inherent to the promoted and displayed intimacy that is produced by the platform's core travel philosophy. At the same time, the coordinated practices of care and hospitality hint at changing dynamics between the people who make home, and the changing relationship between them.

\section{Changing relationalities of home}

"[In the beginning] my girlfriend did not feel safe in the house while we were hosting beautiful women." Adrian

"[Hosting] empowers my mother, because she gets to see the world just by sitting in her room. Airbnb is empowering, this [economy] wouldn't be possible twenty years ago. Just like with one click creating a... I don't know... put some photos online and people come here from everywhere. So yeah, I think it is very powerful and this experience is changing her life. Because she is getting in touch with different cultures, different people." Nico

The unfixed and dynamic nature of home is reflected in the two different accounts of Airbnb hosts Adrian and Nico. When relative strangers temporarily move in, it is not just the dynamic between hosts and guests that challenge the meaning of home, similarly those already "at home" may start 
relating differently to one another and to their homes. Adrian had to "work hard" to convince his partner that these "beautiful" Airbnb guests who had entered the safe haven of their relationship, their home, posed no threat to its fidelity. This particular case illustrates that ideas of home are defined in comparison with what is not a home: a place of sexual promiscuity or infidelity. It attests of a relational understanding of home, in which material and imaginative geographies of home are forged in relation to "foreign" or "unhomely" practices (Blunt \& Dowling 2006, 142). Adrian's account further reveals a normative understanding of home as a heterosexual place that facilitates everyday heterosexual practices and intimacies (e.g., Gorman-Murray 2006; Johnston \& Longhurst 2009, chapter 3; Morrison 2012). Home, here, is supposedly a monogamously "safe" location that is unsettled by the arrival of the sexualized and supposedly "predatory" stranger-guests.

The presence of stranger-guests, however, can similarly destabilize home as a space of alienation and oppression, which is mirrored in Nico's account. While home in early feminist accounts has been described as a place that removes women from politics and business (see Blunt \& Dowling 2006), the Airbnb-home-as-work-and-travel-destination also empowered Anne and brought renewed self-fulfilment. Throughout her adult life, Anne had expressed her sense of self as a mother through home-making practices in her apartment. After Nico left home to work abroad - and Anne was consequently left with Nico's empty room - it was Nico (a fervent Airbnb-traveller himself) who proposed to rent out his old bedroom on the Airbnb platform. In this way, the empty bedroom could temporarily bring new life to their home and the derived income could cover the basic costs of living of Anne, who had been unemployed for some time.

With Nico's bedroom taking on a different purpose and becoming imbued with monetary and symbolic values on the Airbnb platform, Anne began feeling validated for her home-making practices that had sometimes gone unrewarded or taken for granted throughout her life. Anne has progressively started to relate differently to her home and Nico's empty bedroom, which throughout her life had been marked by her role as mother and home-maker. She also began to take on a different sense of herself as an entrepreneur in this newfound economy and came to identify herself as a knowledgeable "local" vis-à-vis the Airbnb guests. This echoes that the relation between individual subjects and places gives places, like home, meaning and their identity (Massey 1991, 1994).

In analysing Nico's and Anne's account, I also recalled Massey's progressive sense of place (1991, 25 ) by giving account of the shift in the power-geometry that began to take place in Anne's home. The initial social relations that made up home before Nico left the house to work abroad began to alter and changed what home came to mean. Besides being mother and son, Anne and Nico have now also become "professional" partners and both take up different roles in commodifying their home through Airbnb. This is to say that the new sharing economy is not merely about the experiences and the evolving relations between hosts and guests: with renting out home come new divisions of labour, new value-generating activities and materialities, and revalorization of social relations that have long existed within the household.

While the increasing presence of "others" may challenge a comfortable sense of belonging (Lloyd \& Vasta 2017, 1), as was the case with Adrian and his partner, it may also challenge the naturalized meanings of home as a place of constraint and oppression. Before starting their Airbnb, Anne's home-making practices never really put her much on the receiving-end of the values those practices generated. The beds she made, the meals she cooked, the bathroom she cleaned, these were all naturalized and normalized practices associated with her role as a mother. Now, her guests oftentimes showed appreciation and paid her for her efforts and explicitly acknowledged her efforts in written testimonies online.

In their newfound economy, Nico and Anne made an arrangement on how to organize and divide the labour it entails to make-home for their guests; an arrangement that is equally gendered. Nico takes care of the written online communication with (potential) guests. He "pre-selects" the guests he would like to stay with his mother by checking their credentials. He takes on bookings, manages the accounting, and does "quality-control" by monitoring and relaying the reviews and ratings of Anne's performances as a host. Nico carries out the administrative and managerial work behind his desk, somewhere away from home. Anne, on the other hand, takes on the preparatory work, cleans the rooms, welcomes the guests upon arrival and carries out the emotional and caring labour when 
guests are around. She also advises her guests on which places to visit when they are in Sofia, if they speak the same language that is. After transactions have taken place, it is Anne who receives the monetary compensation for their joint efforts.

Importantly, while the commodification of home may (re)valorise and (re)signify home-making practices, it does not necessarily eliminate the presence of the broader gender inequality in the Airbnb household, especially considering the aforementioned division of labour between Nico and Anne. Like Meah and Jackson $(2013,592)$ in their study on middle-class households, making-home in the Airbnb economy is mostly a lifestyle choice for the men whom I interviewed and stayed with during my fieldwork. The "new and cool" rhetoric espoused by the technologically advanced Airbnb platform has, to some extent, de-stigmatized domestic chores both as low-status work (Schor 2017, 275) as well as inherently feminine work. However, several hosts expressed that household chores and the work associated with hosting are still seen as a "nuisance" and in some cases are therefore outsourced to "other" women. Future studies may thus consider shedding light on the possibly gendered, racialized and classed labour that currently takes place in the sharing economies of tourism and tell us more about the power relations that these economies bring forth, or, perpetuate.

\section{Conclusion}

In this paper, I have reflected on the situated and embodied everyday performances of home taking place within the Airbnb context. While the platform seemingly rotates around a relatively essentialized idea of home as a place of "belonging", this study has hopefully demonstrated the inherent contested nature of home in the sharing economy. In doing so, this paper contributes to the existing literature on the critical geographies of home (Brickell 2012). Like Lloyd and Vasta (2017), who propose to move away from home as a static location and instead employ an understanding home as "practiced", I have suggested to explore home as "performed". Drawing on Butler's conceptualization of performance, I have tried to show that while home is often considered a stable construct, home is continuously "done" or "undone" in relation to something or someone other (Butler 2004). Foregrounding performance as an analytical approach, this paper has attempted to stimulate thinking beyond what home is, and to reflect instead on how home becomes (un)homely (Blunt \& Dowling 2006, 26).

In the case discussed here, the political and historical specificities, as well as the materialities of the visited homes have significantly shaped the ways in which the ordinary practices of homemaking unfolded. During my fieldwork, the materialities of home shaped the conditions that led to a deeply embodied sensation of "unhomeliness" on my part - while, at the same time, strongly shaped my appreciation of the hosts' everyday lives. Similarly, a variety of apparently trivial and undervalued objects in the home were (re-)engaged with in order to stage, in the words of Goffman (1956) and MacCannell (2013), an experience of "real life" under socialism. These objects thus imbued significant use-value as well as a symbolic value in the performance of home (Haldrup \& Larsen 2006): while satisfying the guests desires for an "authentic" experience of home, the materialities of home were also crucial in making homely geographies performable.

Throughout my stays, a complex mix of corporeal and affective practices continuously reconstituted home as an intimate spatiality; one in which it was never quite clear who was the guest and who was the host. The performances of Airbnb homes in this paper capture the ambiguity of the often taken-for-granted opposition between host and guest. Moreover, such performances challenge home as a place of belonging or non-belonging (Blunt \& Dowling 2006, 255). Some of my hosts, for instance, admitted being self-disciplined into silent bodies or deliberately discounted their own intimate practices around the house to avoid the disruption of their guests' sense of home. By means of "giving more space to the guests" some of my hosts went so far as to (temporarily) "erase" themselves from the shared spaces of their apartments and provided the visitors with a sense of being in a "private" home of their own. Other hosts (implicitly) bordered certain intimate spaces, such as their bedroom, or, alternatively shared certain intimate practices only with some guests, but not with others. By performing imaginary "insides" and "outsides" within the home, they attempted to maintain or protect their own sense of "homeliness" while having guests around. 
Similarly, I engaged in various embodied practices that I sensed pertained to the norms of "appropriateness" and "hygiene" in those specific contexts. As such, home does not come into being through one singular act but through reiterative and citational practices (Butler 2011) that are guided by normative understandings of home.

Finally, what my experience in Sofia has shown is that the homes involved in the Airbnb platform economy represented a key site through which social relations took on a new direction and meaning. Importantly, this study has proposed to move away from the emphasis on encounters and relations between "strangers" (e.g., Bialski 2012; Germann Molz 2007, 2014; Picard \& Buchberger 2013) and to detail instead how the arrival of a stranger-guest unsettles and reshapes the relations between those already at home. Through Airbnb, relationships may expand from being merely familial to becoming also entrepreneurial, bringing about a whole new set of responsibilities towards each other. Moreover, in some cases, renting out home through Airbnb has provoked in some households a re-division of labour in "making-home" amongst each other. Commodifying home has also changed the ways in which people relate to each other and their home. Home, here, produces its identity and continuously constructs its past through shifting social relations. This echoes Massey's $(1992,14)$ critique of the dominant notions of home as an "internally produced, essential past"; a place to which we supposedly "belong". While a place like home may have a character of its own, this is not a unified identity which everyone shares (Massey 1994, 169).

This raises important questions about how "homes", in the sharing economy of Airbnb, are conceived, presented, performed and put into circulation, including the related value production. The platform rhetoric, and the calculative rationalities that underlie its review and rating systems, is supposed to provide a set of objective information concerning the "qualities" of individual homes and of those who perform them locally. Such rather a-historical and a-politicized understanding of home fails to take into consideration that "home" is constituted through the everyday practices of those who inhabit them and, in the case of Airbnb, also through each new encounter between hosts and guests, at times leading to contested and difficult relations generated by the very fact of sharing some of the most intimate spaces.

The everyday "becoming" of home, thus, does not lend itself well to sharp categorizations or essentialised qualifications, as the ones provided by Airbnb's review and rating systems. The homes where I stayed in Sofia did not share a singular element of "local" identity; on the contrary, their meaning and the related performances were continuously redefined through the changing social relations and practices that the encounters between Airbnb hosts and guests produced on a daily basis. In line with Butler's account of the emancipatory potential of thinking through "becoming", home in this project has emerged less as a "local" object to qualify and rank, and more like a negotiated and sometimes contested process: not a place to return to or a point of arrival, rather a point of departure for both hosts and guests.

\section{Acknowledgements}

I want to thank René van der Duim and Ulrich Ermann for their guidance and for their comments on the earlier drafts of this article. For the comments on the following drafts of this article I want to thank the two anonymous referees of Fennia as well as Kirsi Pauliina Kallio and Hanna Salo. This work was supported by the University of Graz through the URBI Faculty's Doctoral Stipend. The 2015 Rudi Roth Grant supported travel and accommodation expenses made during the fieldwork.

\section{References}

Accarigi, I. V. (2017) Transcultural objects, transcultural homes. In Lloyd, J. \& Vasta, E. (eds.) Reimagining Home in the 21 $1^{\text {st }}$ Century, 192-206. Edward Elgar Publishing, Cheltenham. https://doi.org/10.4337/9781786432933.00022

Adkins, L. \& Jokinen, E. (2008) Introduction: gender, living and labour in the fourth shift. NORA Nordic Journal of Feminist and Gender Research 16(3) 138-149.

https://doi.org/10.1080/08038740802300947 
Ahmed, S. (1999) Home and away: narratives of migration and estrangement. International Journal of Cultural Studies 2(3) 329-47. https://doi.org/10.1177/136787799900200303

Airbnb (2017) Fast facts. <https://press.atairbnb.com/fast-facts/>. 17.01.2018.

Allen-Collinson, J. (2013) Autoethnography as the engagement of self/other, self/culture, self/politics, selves/futures. In Holman Jones, S., Adams, T. \& Ellis, C. (eds.) Handbook of Autoethnography, 281299. Routledge, New York.

Andersson Cederholm, E. \& Hultman, J. (2010) The value of intimacy - Negotiating commercial relationships in lifestyle entrepreneurship. Scandinavian Journal of Hospitality and Tourism 10(1) 16-32. https://doi.org/10.1080/15022250903442096

Arias Sans, A. \& Quaglieri Domínguez, A. (2016) Unravelling Airbnb. Urban perspectives from Barcelona. In Russo, P. \& Richards, G. (eds.) Reinventing the Local in Tourism, 209-228. Channel View Publications, Bristol.

Bate, B. (2017) Understanding the influence tenure has on meanings of home and homemaking practices. Geography Compass. https://doi.org/10.1111/gec3.12354

Baxter, R., \& Brickell, K. (2014) For home unmaking. Home Cultures 11(2) 133-143. https://doi.org/10.2752/175174214X13891916944553

Bialski, P. (2012) Becoming Intimately Mobile. Peter Lang, Frankfurt am Main. https://doi.org/10.3726/978-3-653-01584-3

Blunt, A. (2005) Cultural geography: cultural geographies of home. Progress in Human Geography 29(4) 505-515. https://doi.org/10.1191/0309132505ph564pr

Blunt, A. \& Dowling, R. (2006) Home. Routledge, London and New York.

Blunt, A., \& Varley, A. (2004) Geographies of home. Cultural Geographies 11 3-6. https://doi.org/10.1191/1474474004eu289xx

Botsman, R. \& Rogers, R. (2010) What's Mine Is Yours: The Rise of Collaborative Consumption. HarperCollins, New York.

Bowlby, S., Gregory, S. \& McKie, L. (1997) ‘Doing home’: patriarchy, caring, and space. Women's Studies International Forum 20(3) 343-350. https://doi.org/10.1016/S0277-5395(97)00018-6

Brickell, K. (2012) 'Mapping'and 'doing'critical Geographies of home. Progress in Human Geography 36(2) 225-44. https://doi.org/10.1177/0309132511418708

Brickell, K. (2014) 'Plates in a basket will rattle': marital dissolution and home 'unmaking' in contemporary Cambodia. Geoforum 51 262-272. https://doi.org/10.1016/j.geoforum.2012.12.005

Brickell, K., Fernández Arrigoitia, M. \& Vasudevan, A. (2017) Geographies of Forced Eviction:Dispossession, Violence, Resistance. Palgrave Macmillan, London. https://doi.org/10.1057/978-1-137-51127-0

Butler, J. (1986) Sex and gender in Simone de Beauvoir's second sex. Yale French Studies 72 35-49. https://doi.org/10.2307/2930225

Butler, J. (1988) Performative acts and gender constitution: an essay in phenomenology and feminist theory. Theatre Journal 40(4) 519-531. https://doi.org/10.2307/3207893

Butler, J. (1990) Gender Trouble. Routledge, New York and London.

Butler, J. (2004) Undoing Gender. Routledge, New York and London.

Butler, J. (2011) Bodies that Matter. On the Discursive Limits of Sex. Routledge, New York and London.

Chesky, B. (2014) Belong anywhere. Airbnb 16.07.2014 <http://blog.atairbnb.com/belong-anywhere/>. 07.10.2017.

Cocola-Gant, A. (2016) Holiday rentals: the new gentrification battlefront. Sociological Research Online 21(3) 1-9. https://doi.org/10.5153/sro.4071

Cocola-Gant, A. \& Pardo, D. (2017) Resisting tourism gentrification: the experience of grassroots movements in Barcelona. Urbanistica Tre, Giornale Online di Urbanistica 5(13) 39-47.

Di Domenico, M. \& Lynch, P. A. (2007) Host/guest encounters in the commercial home. Leisure Studies 26(3) 321-338. https://doi.org/10.1080/02614360600898110

Dowling, E. (2012) The waitress: on affect, method and (re)presentation. Cultural Studies Critical Methodologies 12(2) 109-17. https://doi.org/10.1177/1532708611435215

Dredge, D. \& Gyimóthy, S. (2017) Collaborative Economy and Tourism Perspectives, Politics, Policies and Prospects. Springer, Cham.

Dupuis, A. \& Thorns, D. C. (1998) Home, home ownership and the search for ontological security. The Sociological Review 46(1) 24-47. https://doi.org/10.1111/1467-954X.00088

Duyvendak, J. (2011) The Politics of Home. Palgrave Macmillan, Basingstoke.

Edelman, B., Luca, M. \& Svirsky, D. (2017) Racial discrimination in the sharing economy: evidence from a field experiment. American Economic Journal: Applied Economics 9(2) 1-22.

https://doi.org/10.1257/app.20160213 
Edensor, T. (2001) Performing tourism, staging tourism. Tourist Studies 1(1) 59-81. https://doi.org/10.1177/146879760100100104

Ellingsen, W. G. \& Hidle, K. (2013) Performing home in mobility: second homes in Norway. Tourism Geographies 15(2) 250-267. http://doi.org/10.1080/14616688.2011.647330

Fahs, B. (2017) The dreaded body: disgust and the production of 'appropriate' femininity. Journal of Gender Studies 26(2) 184-96. https://doi.org/10.1080/09589236.2015.1095081

Frenken, K. \& Schor, J. (2017) Putting the sharing economy into perspective. Environmental Innovation and Societal Transitions 23 3-10. https://doi.org/10.1016/j.eist.2017.01.003

Germann Molz, J. (2007) Cosmopolitans on the couch: mobile hospitality and the Internet. In Germann Molz, J. \& Gibson, S. (eds.) Mobilizing Hospitality: The Ethics of Social Relations in a Mobile World, 65-83. Ashgate, Aldershot UK.

Germann Molz, J. (2008) Global abode: home and mobility in narratives of round-the-world travel. Space and Culture 11(4) 325-342. https://doi.org/10.1177/1206331207308333

Germann Molz, J. (2012) Social networking technologies and the moral economy of alternative tourism: the case of Couchsurfing.org. Annals of Tourism Research 43 210-230. https://doi.org/10.1016/j.annals.2013.08.001

Germann Molz, J. (2014) Toward a network hospitality. First Monday 19(3). https://doi.org/10.5210/fm.v19i3.4824

Gill, R. \& Pratt, A. (2008) In the social factory? Immaterial labour, precariousness and cultural work. Theory, Culture \& Society 25(7-8) 1-30. https://doi.org/10.1177/0263276408097794

Gillespie, T. (2017) The platform metaphor revisited. HIIG science blog 24.08.2017 <https://www. hiig. de/en/blog/the-platform-metaphor-revisited/>. 05.10.2017.

Goffman, E. (1956) The Presentation of Self in Everyday Life. University of Edinburgh, Edinburgh.

Gorman-Murray, A. (2006) Gay and lesbian couples at home: identity work in domestic space. Home Cultures 3(2) 145-167. https://doi.org/10.2752/174063106778053200

Gregson, N. \& Lowe, M. (1995) 'Home'-making: on the spatiality of daily social reproduction in contemporary middle-class Britain. Transactions of the Institute of British Geographers 20(2) 224235. https://doi.org/10.2307/622433

Gregson, N. \& Rose, G. (2000) Taking Butler elsewhere: performativities, spatialities and subjectivities. Environment and Planning D 18(4) 433-452. https://doi.org/10.1068/d232

Gurran, N., Phibbs, P. (2017) When tourists move in: how should urban planners respond to Airbnb? Journal of the American Planning Association 83(1) 80-92. https://doi.org/10.1080/01944363.2016.1249011

Gyimóthy, S. (2017) Networked cultures in the collaborative economy. In Dredge, D. \& Gyimóthy, S. (eds.) Collaborative Economy and Tourism: Perspectives, Politics, Policies and Prospects, 59-74. Springer, Cham. https://doi.org/10.1007/978-3-319-51799-5_5

Haldrup, M. (2009) Banal tourism? Between cosmopolitanism and orientalism. In Pons, P. O., Crang, M. \& Travlou, P. (eds.) Cultures of Mass Tourism: Doing the Mediterranean in the Age of Banal Mobilities, 53-74. Routledge, London and New York.

Haldrup, M. (2017) Souvenirs: magical objects in everyday life. Emotion, Space and Society 22 52-60. https://doi.org/10.1016/j.emospa.2016.12.004

Haldrup, M. \& Larsen, J. (2006) Material cultures of tourism. Leisure Studies 25(3) 275-289. https://doi.org/10.1080/02614360600661179

Hardt, M. (1999) Affective labor. Boundary 2 26(2) 89-100. <http://www.jstor.org/stable/303793>

Hardt, M. \& Negri, A. (2000) Empire. Harvard University Press, Cambridge MA.

Haraway, D. J. (1991) Simians, Cyborgs and Women: The Reinvention of Nature. Free Association Books, London.

Harvey, D. (2008) The right to the city. New Left Review 53 23-40.

Hirt, S. (2006) Post-socialist urban forms: notes from Sofia. Urban Geography 27(5) 464-488. https://doi.org/10.2747/0272-3638.27.5.464

Hochschild, A. R. (1997) The Time Bind: When Home Becomes Work and Work Becomes Home. Henry Holt, New York.

hooks, b. (1991) Yearning: Race, Gender, and Cultural Politics. Turnaround, London.

Isaksen, L. (2002) Toward a sociology of (gendered) disgust: images of bodily decay and the social organization of care work. Journal of Family Issues 23(7) 791-811. https://doi.org/10.1177/019251302236595

Jarvis, H. \& Pratt, A. C. (2006) Bringing it all back home: the extensification and 'overflowing'of work: the case of San Francisco's new media households. Geoforum 37(3) 331-339.

https://doi.org/10.1016/j.geoforum.2005.06.002 
Johnston, L., \& Longhurst, R. (2009) Space, Place, and Sex: Geographies of Sexualities. Rowman \& Littlefield, Boulder CO.

Kaneva, N. \& Popescu, D. (2011) National identity lite: nation branding in post-communist Romania and Bulgaria. International Journal of Cultural Studies 14(2) 191-207. https://doi.org/10.1177/1367877910382181

Kapital (2017) Airbnb or long-term rent? 08.04.2017 <https://www.capital.bg/biznes/moiat kapital/2017/04/08/2949437 airbnb ili dulgosrochen_naem/>. 12.01.2018

Karlsson, L., Kemperman, A., \& Dolnicar, S. (2017) May I sleep in your bed? Getting permission to book. Annals of Tourism Research 62 1-12. https://doi.org/10.1016/j.annals.2016.10.002

Kirshenblatt-Gimblett, B. (1998) Destination Culture: Tourism, Museums, and Heritage. University of California Press, Berkeley and Los Angeles.

Knox, P. \& Pinch, S. (2014) Urban Social Geography: An Introduction. Routledge, London and New York.

Koycheva, L. (2016) When the radical is ordinary: ridicule, performance and the everyday in Bulgaria's protests of 2013. Journal of Contemporary European Studies 24(2) 240-254. https://doi.org/10.1080/14782804.2016.1170002

Larsen, J. (2008) De-exoticizing tourist travel: everyday life and sociality on the move. Leisure Studies 27(1) 21-34. https://doi.org/10.1080/02614360701198030

Lee, D. (2016) How Airbnb short-term rentals exacerbate Los Angeles's affordable housing crisis: analysis and policy recommendations. Harvard Law \& Policy Review 10(1) 229-254.

Lloyd, J. \& Vasta, E. (2017) Reimagining Home in the $21^{\text {st }}$ Century. Edward Elgar Publishing, Cheltenham. https://doi.org/10.4337/9781786432933

Lynch, P., McIntosh, A. J., \& Tucker, H. (eds.) (2009) Commercial Homes in Tourism: An International Perspective. Routledge, London and New York.

MacCannell, D. (2013) The Tourist: A New Theory of the Leisure Class. University of California Press, Berkeley and Los Angeles.

Mallett, S. (2004) Understanding home: a critical review of the literature. The Sociological Review 52(1) 62-89. https://doi.org/10.1111/j.1467-954X.2004.00442.x

Marston, S. A. (2000) The social construction of scale. Progress in Human Geography 24(2) 219-242. https://doi.org/10.1191/030913200674086272

Marston, S. A. (2004) A long way from home: domesticating the social production of scale. In Sheppard, E. \& McMaster, R. (eds.) Scale and Geographic Inquiry: Nature, Society and Method, 170191. Blackwell, Oxford. https://doi.org/10.1002/9780470999141.ch9

Massey, D. (1991) A global sense of place. Marxism Today 38 24-29.

Massey, D. (1992) A place called home. Formations 17 3-15.

Massey, D. (1994) Space, Place and Gender. University of Minnesota Press, Minneapolis.

McDowell, L. (2004) Gender, Identity and Place: Understanding Feminist Geographies. Polity Press, Cambridge.

Meah, A. \& Jackson, P. (2013) Crowded kitchens: the "democratisation" of domesticity? Gender, Place \& Culture 20(5) 578-596. https://doi.org/10.1080/0966369X.2012.701202

Minca, C. \& Oakes, T. (2011) Real Tourism: Practice, Care, and Politics in Contemporary Travel Culture. Routledge, London and New York.

Minchev, O. (2013) Russia's energy monopoly topples the Bulgarian government. GMF 04.03.2013 <http://wWw.gmfus.org/b/og/2013/03/04/russia\%E2\%80\%99s-energy-monopoly-topples-bulgariangovernment>. 05.10.2017.

Ministry of Tourism Bulgaria (2018) Bulgarian Tourism Law. <http://www.tourism.government.bg/bg/ kategorii/zakoni>.18.01.2018

Mitchell, K., Marston, S. A. \& Katz, C. (2004) Life's work: an introduction, review and critique. In Mitchell, K., Marston, S. A. \& Katz, C. (eds.) Life's Work. Geographies of Social Reproduction, 1-26. Wiley-Blackwell, Oxford. https://doi.org/10.1002/9781444397468.ch

Mohanty, C. T. (2003) Feminism Without Borders: Decolonizing Theory, Practicing Solidarity. Duke University Press, Durham and London. https://doi.org/10.1215/9780822384649

Morgan, N., \& Pritchard, A. (2005) On souvenirs and metonymy: narratives of memory, metaphor and materiality. Tourist Studies 5(1) 29-53. https://doi.org/10.1177/1468797605062714

Morrison, C.-A. (2012) Heterosexuality and home: intimacies of space and spaces of touch. Emotion, Space and Society 5(1) 10-18. https://doi.org/10.1016/j.emospa.2010.09.001

Picard, D., \& Buchberger, S. (eds.) (2013) Couchsurfing Cosmopolitanisms: Can Tourism Make a Better World? Transcript Verlag, Bielefeld. https://doi.org/10.14361/transcript.9783839422557

Pratt, M. L. (2008) Imperial Eyes: Travel Writing and Transculturation. Routledge, London and New York. 
Richards, G. (2017) Sharing the new localities of tourism. In Dredge, D. \& Gyimóthy, S. (eds.) Collaborative Economy and Tourism: Perspectives, Politics, Policies and Prospects, 169-184. Springer, Cham. https://doi.org/10.1007/978-3-319-51799-5_10

Roelofsen, M. \& Minca, C. (2018) The Superhost. Biopolitics, home and community in the Airbnb dreamworld of global hospitality. Geoforum 91 170-181. https://doi.org/10.1016/j.geoforum.2018.02.021

Russo, A. P. \& Richards, G. (2016) Reinventing the Local in Tourism: Producing, Consuming and Negotiating Place. Channel View Publications, Bristol.

Scarles, C. (2010) Where words fail, visuals ignite. Opportunities for visual autoethnography in tourism research. Annals of Tourism Research 37 905-926. https://doi.org/10.1016/j.annals.2010.02.001

Schor, J. B. (2017) Does the sharing economy increase inequality within the eighty percent? Findings from a qualitative study of platform providers. Cambridge Journal of Regions, Economy and Society 10 263-279. https://doi.org/10.1093/cjres/rsw047

Spry, T. (2001) Performing autoethnography: an embodied methodological praxis. Qualitative Inquiry 7(6) 706-732. https://doi.org/10.1177/107780040100700605

Sweeney, M., \& Lynch, P. (2007) Explorations of the host's relationship with the commercial home. Tourism and Hospitality Research 7(2) 100-108. https://doi.org/10.1057/palgrave.thr.6050042

Tsvetelia, T. (2013) Bulgarian protests for cheaper energy intensify. Reuters World News 24.02.2013. <http://www.reuters.com/article/us-bulgaria-government-protests/bulgarian-protests-for-cheaperenergy-intensify-idUSBRE91N06D20130224>. 05.10.2017.

Veijola, S. \& Valtonen, A. (2007) The body in tourism industry. In Pritchard, A., Morgan, N., Ateljevic, I., \& Harris, C. (eds.) Tourism and Gender: Embodiment, Sensuality and Experience, 13-31. CABI, Oxfordshire. https://doi.org/10.1079/9781845932718.0013

Veijola, S., Germann Molz, J., Pyyhtinen, O., Hockert, E., Grit, A. \& Höckert, E. (2014) Disruptive Tourism and Its Untidy Guests: Alternative Ontologies for Future Hospitalities. Palgrave Macmillan UK, London. https://doi.org/10.1057/9781137399502

Wachsmuth, D., Chaney, D., Kerrigan, D., Shillolo, A. \& Basalaev-Binder, R. (2018) The high cost of short-term rentals in New York City. A report from the Urban Politics and Governance research group, School of Urban Planning, McGill University. <http://www.sharebetter.org/wp-content/ uploads/2018/01/High-Cost-Short-Term-Rentals.pdf>. 02.02.2018.

Young, I. M. (1997) Intersecting Voices: Dilemmas of Gender, Political Philosophy, and Policy. Princeton University Press, Princeton NJ.

Zuev, D. (2013) Couchsurfing along the Trans-Siberian railway and beyond: cosmopolitan learning through hospitality in Siberia. Sibirica: Interdisciplinary Journal of Siberian Studies 12(1) 56-82. https://doi.org/10.3167/sib.2013.120103 